\title{
Pengaruh Kinerja Keuangan Bank Terhadap Koefisien Respon Laba Melalui Investment Opportunity Set (Studi Kasus pada Bank Umum yang Terdaftar di Bursa Efek Indonesia Periode Tahun 2011-2016)
}

\author{
Atti Rasnawati \\ STIE Graha Karya Muara Bulian \\ Correspondence email: rasnawatiaty@yahoo.co.id
}

\begin{abstract}
This research raises the issue of banking performance including Risk Profile, Good Corporate Governance, Earning and Capital (RBBR or RGEC). Profit achieved by a company is a measure of performance and is considered by investors or creditors in making decisions to make investments or to provide additional credit. The low quality of earnings will make the decision making mistakes of the users such as investors and creditors, so that the value of the company will decrease. Earnings quality will be measured by using earnings response coefficient. Low The earnings response coefficient shows that earnings are less informative or in other words less qualified for investors to make economic decisions. The purpose of this study was to examine and determine the EFFECT of the Bank's Financial Performance on the Coefficient of Earnings Response through the Investment Opportunity Set. The analysis tools used include CAR, NPL, LDR, NIM, and GCG for bank financial performance. Then MBVE for investment opportunity set and for KRL using CAR, EU and RT. The results of this study indicate that the bank's financial performance has a positive and insignificant effect on the earnings response coefficient and earnings response coefficient can be explained by the bank's financial performance of $28.5 \%$ and the remaining $71.5 \%$ is explained by other variables outside the financial performance of the bank under study. Then the bank's financial performance has a negative and significant effect on the investment opportunity set and the earnings response coefficient can be explained by the bank's financial performance of 10.1\% and the remaining $89.9 \%$ is explained by other variables outside the financial performance of the bank under study. Furthermore, the investment opportunity set has a positive and significant effect on the earnings response coefficient and the earnings response coefficient can be explained by an investment opportunity set of $26.4 \%$ and the remaining $73.6 \%$ is explained by other variables outside the financial performance of the bank under study.
\end{abstract}

Keywords: banking performance, risk profile, good corporate governance, earning and capital

\section{Pendahuluan}

Otoritas dan analis keuangan dunia telah mengamati dengan cermat krisis yang terjadi di asia pada tahun 1990 dan krisis berikutnya sampai dengan terjadi krisis keuangan global yang melanda negara dalam kurun waktu beberapa tahun terakhir di tahun 2008. Perkembangan dunia perbankan sangat pesat setelah terjadi deregulasi dibidang keuangan, moneter dan perbankan pada juni 1983. Deregulasi tersebut telah mengakibatkan kebutuhan dana secara langsung maupun tidak langsung melalui perbankan meningkat. Mengulas kegiatan ekonomi tidak lepas dari dunia perbankan tahun 1997/1998 menjadi pelajaran penting dalam bisnis perbankan. Bank kesulitan likuiditas, kualitas asset memburuk, tidak mampu menciptakan earning dan akhirnya modal terkuras dalam waktu yang sangat cepat dan kondisi ini berlangsung hingga tahun 2004. Peranan perbankan saat ini sangat dominan dalam sistem keuangan, sehingga pemahaman dan pengelolaan bank yang baik tentunya akan mendorong sistem keuangan yang baik. Apalagi kemudian pemahaman kita diperkaya dengan berbagai pemaparan mengenai pengelolaan rasio keuangan, penilaian kinerja dan tingkat kesehatan yang memadai. Berangkat dari pemikiran tersebut lingkup materi tentang analisis rasio keuangan perbankan dirasakan masih sangat diupayakan dan dibutuhkan demi kepentingan semua pihak.

Dalam upaya meningkatkan pertumbuhan ekonomi dan kesejahteraan masyarakat, pemerintah menyadari bahwa peranan bank sangat penting. Bank adalah sebuah lembaga atau perusahaan yang aktivitasnya menghimpun dana berupa giro, deposito tabungan dan simpanan yang lain dari pihak yang kelebihan dana (surplus spending unit), kemudian menempatkannya kembali kepada masyarakat yang membutuhkan dana melalui penjualan jasa keuangan yang pada gilirannya dapat meningkatkan kesejahteraan masyarakat. Dunia usaha dalam menjalankan usahanya tidak lepas dari dukungan bank baik peranan bank sebagai peranan dalam lalu lintas pembayaran, penghimpun dana maupun penyalur dana (kuncoro dan suhardjono 2002). Perbankan sebagai suatu lembaga yang berfungsi menghimpun dan menyalurkan dana masyarakat pada akhirnya akan memiliki peranan yang strategis untuk mendukung pelaksanaan pembangunan nasional, yakni dalam rangka meningkatkan pemerataan pembangunan dan hasil-hasilnya, pertumbuhan ekonomi dan stabilitas nasional kearah peningkatan taraf hidup rakyat banyak.

Pasar modal merupakan salah satu instrument ekonomi dewasa ini yang mengalami perkembangan sangat pesat. Hal ini terjadi tidak terlepas dari berkembangnya investasi akhir-akhir ini yang disebabkan kemudahan berinvestasi, deregulasi peraturan, dan kebebasan aliran informasi juga merupakan sarana untuk melakukan investasi yaitu 
Atti Rasnawati, Pengaruh Kinerja Keuangan Bank Terhadap Koefisien Respon Laba Melalui Investment Opportunity Set (Studi Kasus pada Bank Umum yang Terdaftar di Bursa Efek Indonesia Periode Tahun 2011-2016)

memungkinkan para investor untuk melakukan diversifikasi investasi, membentuk portofolio sesuai dengan resiko yang bersedia mereka tanggung dan tingkat keuntungan yang diharapkan. Investasi pada sekuritas juga bersifat likuid (mudah berubah) oleh karena itu, penting bagi suatu perusahaan untuk selalu memperhatikan kepentingan para investor dengan jalan memaksimalkan nilai perusahaan karena nilai perusahaan merupakan ukuran keberhasilan atas pelaksanaan fungsifungsi keuangan. Investor dalam menilai kerja manajemen perusahaan dapat dilihat melalui laporan keuangan yang diterbitkan. Untuk dapat memilih investasi yang aman diperlukan suatu analisa yang cermat, teliti dan didukung dengan data-data yang akurat. Tekhnik yang benar dalam analisa akan mengurangi resiko bagi investor dalam berinvestasi. Dengan adanya analisa diharapkan modal yang diinvestasikan akan menghasilkan keuntungan yang maksimal dan aman dan jika ada resiko, resiko lebih kecil dibandingkan dengan kemungkinan yang dapat diraih.

Saham merupakan bentuk instrument finansial yang menunjukan kepemilikan seseorang atau suatu badan terhadap suatu perusahaan. Saham digunakan oleh perusahaan yang mengeluarkannya untuk mendapat modal tambahan dengan menjualnya kepada para investor. Para investor membelinya dengan tujuan untuk mendapat keuntungan atas asset dan profit perusahaan tersebut berdasarkan jumlah saham yang dimilikinya. Keuntungan lainnya juga dapat diperoleh investor, jika menjual saham dengan harga yang lebih tinggi dari harga beli. Adapun masalah yang selalu mengikuti kegiatan investasi menggunakan saham adalah perubahan harga saham yang fluktuatif dalam rentang waktu yang singkat. Hal ini menuntut investor untuk melakukan perhitungan yang cermat agar tidak merugi. Perkembangan harga saham di pasar modal kita beberapa saat terakhir ini telah mendorong banyaknya calon investor yang ingin lebih mengetahui saham-saham yang prospektif untuk dibeli. Untuk keperluan tersebut maka dibutuhkan suatu pemahaman yang mendalam mengenai harga saham itu sendiri dan faktor-faktor yang mempengaruhi pergerakannya.

Bank umum yang terdaftar dibursa efek indonesia berjumlah 43 bank dengan masing - masing kode bank. Industri perbankan telah mengalami perubahan besar dalam beberapa tahun terakhir. Industri ini menjadi lebih kompetitif karena deregulasi peraturan. Saat ini, bank memiliki fleksibilitas pada layanan yang mereka tawarkan, lokasi tempat mereka beroperasi, dan tarif yang mereka bayar untuk simpanan deposan. Kuantitas bank yang banyak menciptakan persaingan yang semakin ketat dan kinerja bank yang menjadi rendah karena ketidakmampuan bersaing di pasar, sehingga banyak bank yang sebenarnya kurang sehat atau bahkan tidak sehat secara financial. Sehat tidaknya suatu perusahaan atau perbankan, dapat dilihat dari kinerja keuangan terutama kinerja profitabilitasnya dalam suatu perusahaan perbankan tersebut. (Fitriani, 2010). Kinerja perbankan meliputi Profil Resiko (Risk Profile), Good Corporate Governance, Earning dan Capital (RBBR atau RGEC) .

Penelitian Yuliani, Muizuddin (2014), Loan to Deposit Ratio atau Rasio likuditas sebagai salah satu rasio keuangan untuk mengukur kinerja keuangan perusahaan menunjukan bahwa kondisi perusahaan adalah likuid. Rasio lokuiditas akan memperkuat hubungan Investment Opportunity Set terhadap nilai perusahaan, dimaknai bahwa dengan kondisi perusahaan yang likuid akan mampu memilih alternatif investasi yang ada sehingga pada akhirnya terjadi peningkatan nilai perusahaan. Suharli (2007) menggarisbawahi penguatan variabel moderasi likuiditas pada 160 perusahaan go publik di pasar bursa indonesia dengan periode 2002-2003 menyebabkan terjadi peningkatan nilai perusahaan. Investment Opportunity Set Berbagai kesempatan investasi sebagai nilai pilihan investasi tergantung pada kebijakan manager untuk melakukan pengeluaran modal masa depan yang dapat dipandang sebagai pilihan pertumbuhan (kole 1991). Investment Opportunity Set merupakan pilihan investasi yang bisa menghasilkan NPV positif, sedangkan pertumbuhan lebih kearah kemampuan manajemen dalam peningkatan nilai perusahaan. Implikasi dari Investment Opportunity Set memainkan peranan penting dalam keuangan perusahaan dalam kaitannya dengan tujuan perusahaan. Investment Opportunity Set juga memiliki peranan yang sangat penting bagi kinerja perusahaan karena merupakan keputusan investasi dalam bentuk kombinasi dari aktiva yang dimiliki (assets in place) dan opsi investasi di masa yang akan datang, dimana Investment Opportunity Set tersebut akan mempengaruhi nilai dan kinerja suatu perusahaan (Pagalung, 2003).

Koefisien respon laba Salah satu arah yang paling penting yang telah diambil oleh penelitian keuangan empiris sejak studi yang dilakukan oleh Ball and Brown adalah identifikasi dan penjelasan respon pasar yang berbeda terhadap informasi laba yang disebut penelitian koefisien respon laba (Scott, 1997). Menurut (Scott, 1997) kualitas laba yang lebih tinggi mempunyai nilai koefisien respon laba yang tinggi koefisien respon laba biasanya digunakan sebagai alternatif untuk mengukur value relevance informasi laba (Lev dan Zarowin, 1999 dalam devira dan nelvirita 2013). Rendahnya koefisien respon laba menunjukan bahwa laba kurang normatif bagi investor untuk membuat keputusan ekonomi. Koefisien respon laba dapat dipengaruhi oleh berbagai faktor, antara lain default risk (resiko gagal bayar) dan konservatisma akuntansi (Diantimala, 2008). Ketika seseorang melakukan investasi, maka salah satu alasannya adalah untuk mendapatkan keuntungan tertentu. Default risk (resiko gagal bayar) yang tinggi seharusnya tidak disukai oleh investor karena apabila terjadi gagal bayar maka investor juga tidak akan mendapatkan return yang seharusnya ia dapatkan . karena itu seharusnya terdapat perbedaan respon laba antara perusahaan dengan default risk tinggi dan rendah.

Salah satu unsur dalam laporan keuangan yang paling banyak diperhatikan dan dinanti-nantikan informasinya adalah laporan laba rugi. Laporan laba rugi merupakan suatu laporan yang memberikan informasi mengenai laba 
(earnings) yang dicapai oleh perusahaan dalam suatu periode. Parawiyati (1996) dalam Kurniati (2010) menyatakan bahwa informasi tentang laba mengukur keberhasilan atau kegagalan bisnis dalam mencapai tujuan operasi yang ditetapkan. Laba yang berhasil dicapai oleh suatu perusahaan merupakan salah satu ukuran kinerja dan menjadi pertimbangan oleh para investor atau kreditur dalam pengambilan keputusan untuk melakukan investasi atau untuk memberikan tambahan kredit. Menurut Fendi (2011) kualitas laba perusahaan merupakan salah satu informasi penting yang tersedia untuk publik dan dapat digunakan investor untuk menilai perusahaan. Rendahnya kualitas laba akan dapat membuat kesalahan pembuatan keputusan para pemakainya seperti investor dan kreditur, sehingga nilai perusahaan akan berkurang. Kualitas laba akan diukur dengan menggunakan Koefisien respon laba (earnings response coefficient). Rendahnya Koefisien respon laba menunjukkan bahwa laba kurang informatif atau dengan kata lain kurang berkualitas bagi investor untuk membuat keputusan ekonomi. Setiap Bank dalam menjalankan kegiatannya untuk terus meningkatkan laba setiap tahunnya agar kinerja perbankan berjalan sesuai dengan yang diharapkan oleh perbankan itu sendiri. Laba dapat dilihat dari seberapa besar ketertarikan investor terhadap saham Masing-masing Bank dan investor dalam menentukan keinginan untuk membeli saham perlu mengetahui nilai buku dalam laporan keuangan sehingga investor bisa melihat besarnya jaminan atau seberapa besar aktiva bersih untuk saham yang dimiliki investor.

Kinerja perbankan juga perlu penilaian untuk terus meningkatkan keuntungan, laporan keuangan yang sesuai dengan keinginan investor dan perkembangan perusahaan sebagai kelanjutan dari kegiatan perusahaan. Investment opportunity set menggambarkan tentang luasnya kesempatan atau peluang investasi bagi suatu perusahaan, namun sangat tergantung pada pilihan expenditure perusahan untuk kepentingan dimasa yang akan datang. Pilihan investasi merupakan suatu kesempatan perusahaan untuk berkembang dan pilihan-pilihan investasi dimasa yang akan datang diharapkan dapat menghasilkan return yang lebih besar.

\section{Tinjauan Pustaka \\ Kinerja keuangan Perusahaan}

Kinerja keuangan adalah suatu analisis yang dilakukan untuk melihat sejauhmana suatu perusahaan telah melaksanakan dengan menggunakan aturan-aturan pelaksanaan keuangan secara baik dan benar. Kinerja perusahaan merupakan suatu gambaran tentang kondisi keuangan suatu perusahaan yang dianalisis dengan alat-alat analisis keuangan, sehingga dapat diketahui mengenai baik buruknya keadaan keuangan suatu perusahaan yang mencerminkan prestasi kerja dalam periode tertentu. Hal ini sangat penting agar sumber daya digunakan secara optimal dalam menghadapi perubahan lingkungan (Fahmi, 2011). Menurut Munawir (2012) menyatakan bahwa tujuan dari pengukuran kinerja keuangan perusahaan adalah: mengetahui tingkat likuiditas; mengetahui tingkat solvabilitas, mengetahui tingkat rentabilitas; dan mengetahui tingkat stabilitas.

Pihak bank dapat menilai kesehatan banknya sendiri dengan menggunakan metode yang baru dikeluarkan pemerintah dalam PBI nomor 13/1/PBI/2011 pasal 2 , disebutkan bank wajib melakukan penilaian tingkat kesehatan bank dengan menggunakan pendekatan risiko (Risk Based Bank Rating) baik secara individual ataupun konsolidasi. Peraturan tersebut menggantikan metode penilaian yang sebelumnya yaitu metode yang berdasarkan Capital, Asset, Management, Earning, Liquidity and Sensitivity to market risk atau yang disebut CAMELS. Metode RBBR menggunakan penilaian terhadap empat faktor berdasarkan Surat Edaran BI No 13/24/DPNP yaitu Risk Profile, Good Corporate Governance, Earning dan Capital.

\section{Risk Based Bank Rating (RBBR)}

Pada peraturan Bank Indonesia No 13/1/PBI/2011 pasal 2, disebutkan bank wajib melakukan penilaian tingkat kesehatan bank dengan menggunakan pendekatan risiko (Risk Based Bank Rating) baik secara individual ataupun konsolidasi. Dalam metode ini terdapat beberapa indikator sebagai acuannya, yaitu :

a. Risk Profile (Profil Risiko), menurut Peraturan Bank Indonesia No.13/1/PBI/2011 profil risiko merupakan penilaian terhadap risiko inheren dan kualitas penerapan manajemen risiko dalam operasional bank yang dilakukan terhadap 8 (delapan) risiko yaitu, risiko kredit, pasar, likuiditas, operasional, hukum, stratejik, kepatuhan dan reputasi. Dalam hal ini untuk mengukur risiko kredit menggunakan rasio Non Performing Loan (NPL) dan rasio Loan to Deposit Ratio (LDR) untuk mengukur risiko likuiditas.

b. Good Corporate Governance (GCG), pelaksanaan GCG bagi bank umum adalah " Good Corporate Governance adalah suatu tata kelola Bank yang menerapkan prinsip-prinsip keterbukaan (transparency), akuntabilitas (accountability), pertanggung jawaban (responsibility), independensi (independency), dan kewajaran (fairness) ". Pelaksanaan GCG pada bank syariah diatur pada PBI Nomor 11/33/PBI/2009 tentang Pelaksanaan Good Corporate Governance bagi Bank Umum Syariah dan Unit Usaha Syariah.

c. Earning (Rentabilitas), penilaian terhadap faktor rentabilitas (earnings) meliputi penilaian terhadap kinerja earnings, sumber-sumber earnings, dan sustainability earnings Bank. Penilaian earning (rentabilitas) diukur dengan menggunakan rasio: 1) Return On Asset (ROA) yang merupakan perbandingan antara laba (net income) 
dengan total asset, dan 2) Net interest Income (NIM), Rasio ini menggambarkan mengenai besarnya margin yang diperoleh bank dengan cara membandingkan antara pendapatan bunga bersih (Net Interest Income/NII) dengan total asset produktif.

d. Capital (Permodalan), capital Adequacy Ratio (CAR) adalah rasio keuangan yang berkaitan dengan permodalan perbankan dimana besarnya modal suatu bank akan berpengaruh pada mampu atau tidaknya suatu bank secara efisien menjalankan kegiatannya. CAR merupakan indikator terhadap kemampuan bank untuk menutupi penurunan aktivanya sebagai akibat dari kerugian-kerugian bank yang disebabkan oleh aktiva-aktiva yang beresiko dengan kecukupan modal yang dimilikinya. Semakin tinggi CAR semakin maka semakin kuat kemampuan bank tersebut untuk menanggung resiko dari setiap kredit atau aktiva produksi yang beresiko.

\section{Investment Opportunity Set}

Investment opportunity set (IOS) merupakan keputusan investasi dalam bentuk kombinasi aktiva yang dimiliki dan pilihan investasi dimasa yang akan datang (Kallapur dan Trombley, 2001) dalam Ahcmad (2006). Investment opportunity set akan diukur dengan menggunakan market to book value of asset ratio. Perusahaan dengan tingkat investment opportunity set tinggi akan memiliki kemampuan menghasilkan laba yang lebih tinggi. Sehingga pasar akan memberi respon yang lebih besar terhadap perusahaan yang mempunyai kesempatan bertumbuh (investment opportunity set). Tingginya respon pasar terhadap laba mengindikasikan bahwa perusahaan memiliki kualitas laba yang baik (Mulyani et al, 2007).. Analisis IOS dalam penelitian ini dengan menggunakan salah satu bentuk proksi IOS yaitu hanya menggunakan sebuah rasio sebagai proksi IOS dalam menjalankan penelitian ini. Rasio yang digunakan yaitu perhitungan market to book value equity (MVE/BVE).

\section{Koefisien Respon Laba}

Pengertian Koefisien Respon Laba (Earnings Response Coefficient) menurut Cho dan Jung 1991 dalam Arna, 2017 adalah sebagai berikut : Koefisien Respon Laba didefinisikan sebagai efek setiap dolar unexpected earnings terhadap return saham, dan biasanya diukur dengan slopa koefisien dalam regresi abnormal returns saham dan unexpected earning. Cho dan Jung (1991) mengklasifikasi pendekatan teoritis Koefisisen respon laba menjadi dua kelompok yaitu (1) model penilaian yang didasarkan pada informasi ekonomi (information economics based valuation model) seperti dikembangkan oleh Holthausen dan Verrechia (1988) dan Lev (1989) yang menunjukkan bahwa kekuatan respon investor terhadap sinyal informasi laba (Earning Respon Coeficient) merupakan fungsi dari ketidakpastian di masa mendatang. Semakin besar noise dalam system pelaporan perusahaan (semakin rendah kualitas laba), semakin kecil Earning Respon Coeficient dan (2) model penilaian yang didasarkan pada time series laba (time series based valuation model) seperti dikembangkan oleh Beaver, Lambert dan Morse (1980). Pengukuran Koefisien Respon Laba; Cumulative Abnormal Return (CAR); Unexpected Earning (UE); Return Tahunan (RT)

\section{Gambar 1 \\ Model Kerangka Pemikiran}




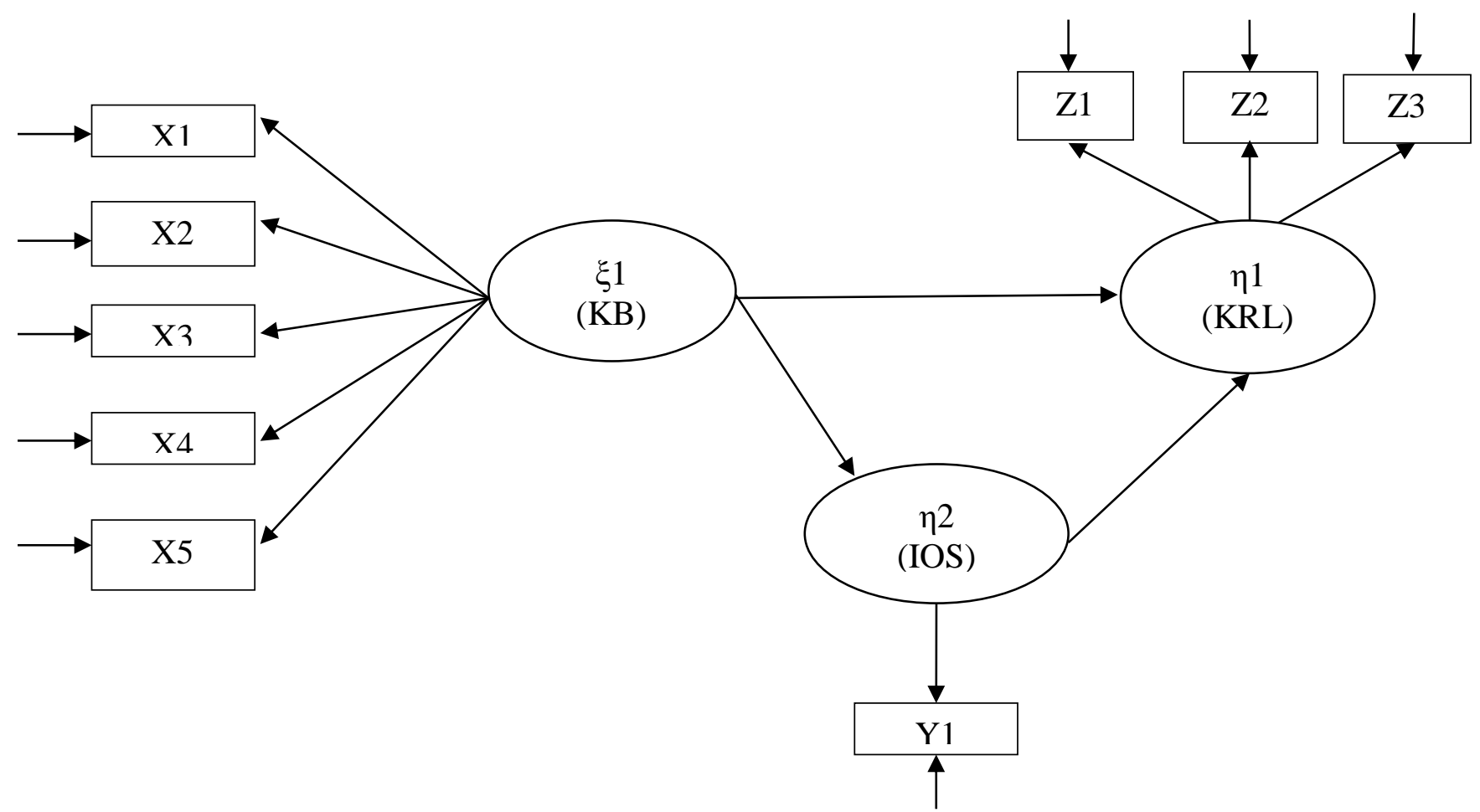

Notasi : $\xi 1=$ Kinerja Keuangan Bank; $\eta 1=$ Koefisien Respon Laba; $\eta 2=$ Investment Opportunity Set X1= Capital Adequacy Ratio; X2 = Net Performing Loan; X3 = Net Interest Margin; X4 = Loan To Deposito Ratio $; \mathrm{X} 5=$ Good Corporate Governance; Y1 = Market To Book Value Of Equity Ratio; Z1 = Cumulatif Abnormal Return; Z2= Unexpected Earning; Z3 = Return tahunan

\section{Metode}

Objek penelitian yang diteliti oleh peneliti yaitu perusahaan sektor keuangan sub sektor bank yang terdaftar di Bursa Efek Indonesia pada tahun 2011-2016. Penelitian ini data yang digunakan dengan menggunakan data sekunder. Data sekunder adalah data yang yang diperoleh oleh peneliti secara tidak langsung dengan adanya perantara pihak lain dan penelitian ini mengambil data keuangan perusahaan perbankan go public melalui kantor Indonesian stock exchange Jambi yaitu laporan tahunan (annual report). Data yang diperoleh bersumber dari data eksternal yaitu data dari kantor Indonesian stock exchange jambi dan bersumber dari literatur-literatur yang berkaitan dengan masalah yang diteliti.

Populasi dalam penelitian ini adalah seluruh sektor keuangan sub sektor perbankan yang go publik pada tahun 2011- 2016 di Bursa Efek Indonesia. Dengan jumlah 43 Bank. Sampel yang dipilih berdasarkan purposive sampling dengan kriteria - kriteria tertentu. Dengan karakteristik sebagai berikut :

Tabel 1

Karakteristik Sampel

\begin{tabular}{llr}
\hline No & \multicolumn{1}{c}{ Karakteristik } & Jumlah \\
\hline 1 & $\begin{array}{l}\text { Perusahaan yang terdaftar di bursa efek indonesia sektor keuangan sub sektor bank yang terdaftar di bursa } \\
\text { efek indonesia periode 2011-2016 }\end{array}$ & 43 \\
2 & $\begin{array}{l}\text { Perusahaan yang terdaftar dibursa efek indonesia sektor keuangan sub sektor bank yang listing setelah tahun } \\
\text { 2011 }\end{array}$ & 13 \\
& $\begin{array}{l}\text { Perusahaan menerbitkan laporan keuangannya selama periode penelitian 2011-2016 dan laporan keuangan } \\
\text { berakhir 31 desember dan dinyatakan dalam rupiah. }\end{array}$ & 30 \\
\hline
\end{tabular}

\section{Alat Analisis Data}

Alat analisa data yang digunakan dalam penelitian ini adalah Partial Least Square (PLS). PLS merupakan metode alternatif analisis dengan Structural Equation Modelling (SEM) yang berbasis variance. Dapat dilihat pada model persamaan struktural berbasiskan komponen atau varian (PLS) yang divisualisasikan dalam gambar berikut:

Model Struktur I : Pengaruh Kinerja Keuangan Bank Terhadap Koefisien Respon Laba 


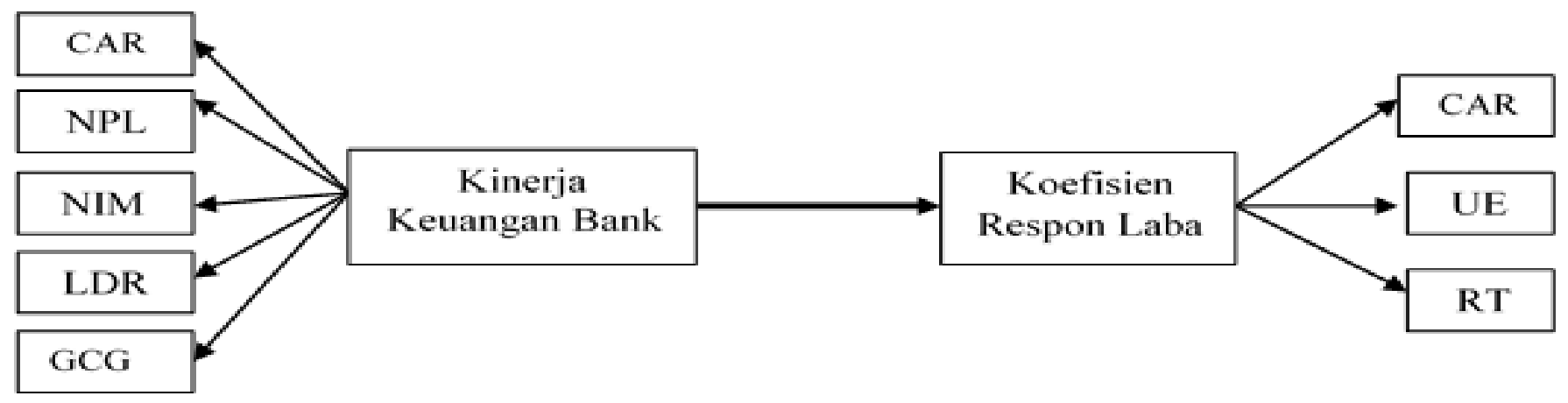

Model Struktur II : Pengaruh Kinerja Keuangan Terhadap Investment Opportunity Set

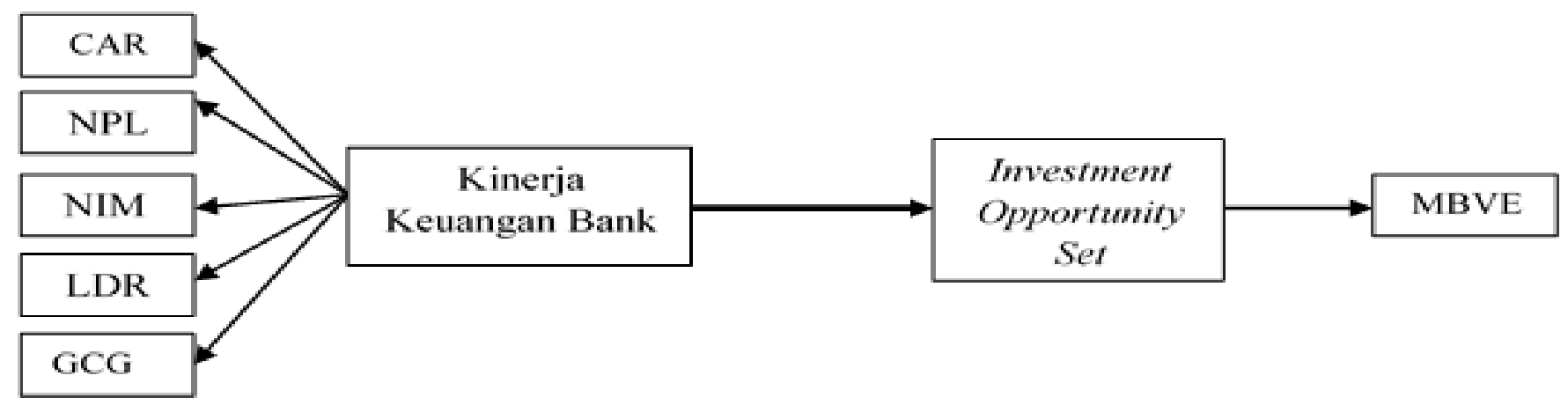

Model Struktur III Pengaruh Investment Opportunity Set Terhadap Koefisien Respon Laba

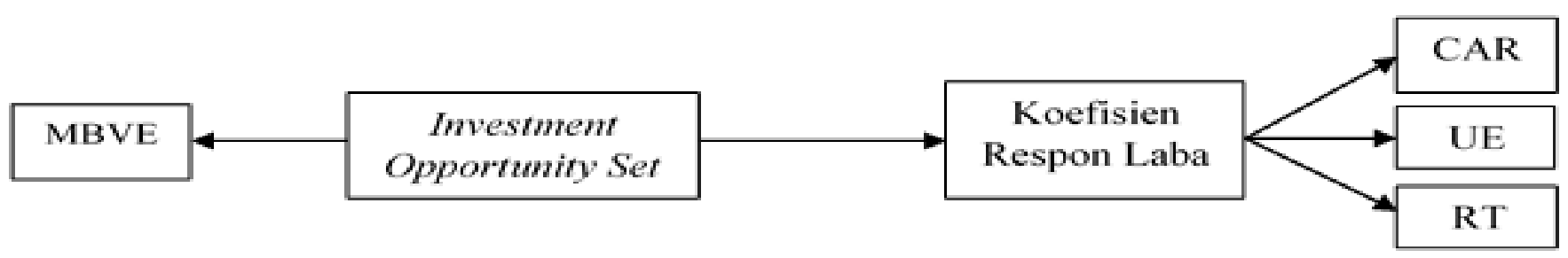

\section{Uji Validitas}

Uji validitas dalam penelitian ini ada dua yaitu :

- Validitas konvergen : hasil pengujian validitas konvergen berupa faktor loading dan AVE. Faktor loading dapat dilihat dengan kriteria : faktor loading >0,70 dan AVE dengan kriteria : AVE >0,50

- Validitas Diskriminan : $\sqrt{ }$ AVE dibandingkan dengan korelasi antar konstruk. Kriteria : $\sqrt{ }$ AVE $>$ korelasi antar konstruk.

Uji Reliabilitas

- $\quad$ Cronbach Alpha, Kriteria : Cronbach Alpha > 0,60

- Composite Reliability, Kriteria : Composite Reliability > 0,60

Evaluasi Model

- $\quad$ R Square : menunjukan koefisien determinasi, sejauh mana suatu konstruk mampu menjelaskan model.

- $\quad$ Q-Square : menunjukan nilai predictive relevance. Q-Square > 0, menunjukan bahwa model mempunyai nilai predictive relevance.

\section{Hasil}

\section{Model PLS}

Dalam struktural diuji dengan menggunakan uji t serta signifikansi dari koefisien parameter jalur struktural. Rancangan analisis dengan menggunakan PLS (Partial Least Square) yang menunjukan pengaruh kinerja keuangan bank terhadap koefisien respon laba melalui investment opportunity set perusahaan perbankan dapat dilihat pada model persamaan struktural berbasis komponen atau varian (PLS) yang divisualisasikan dalam gambar berikut : 


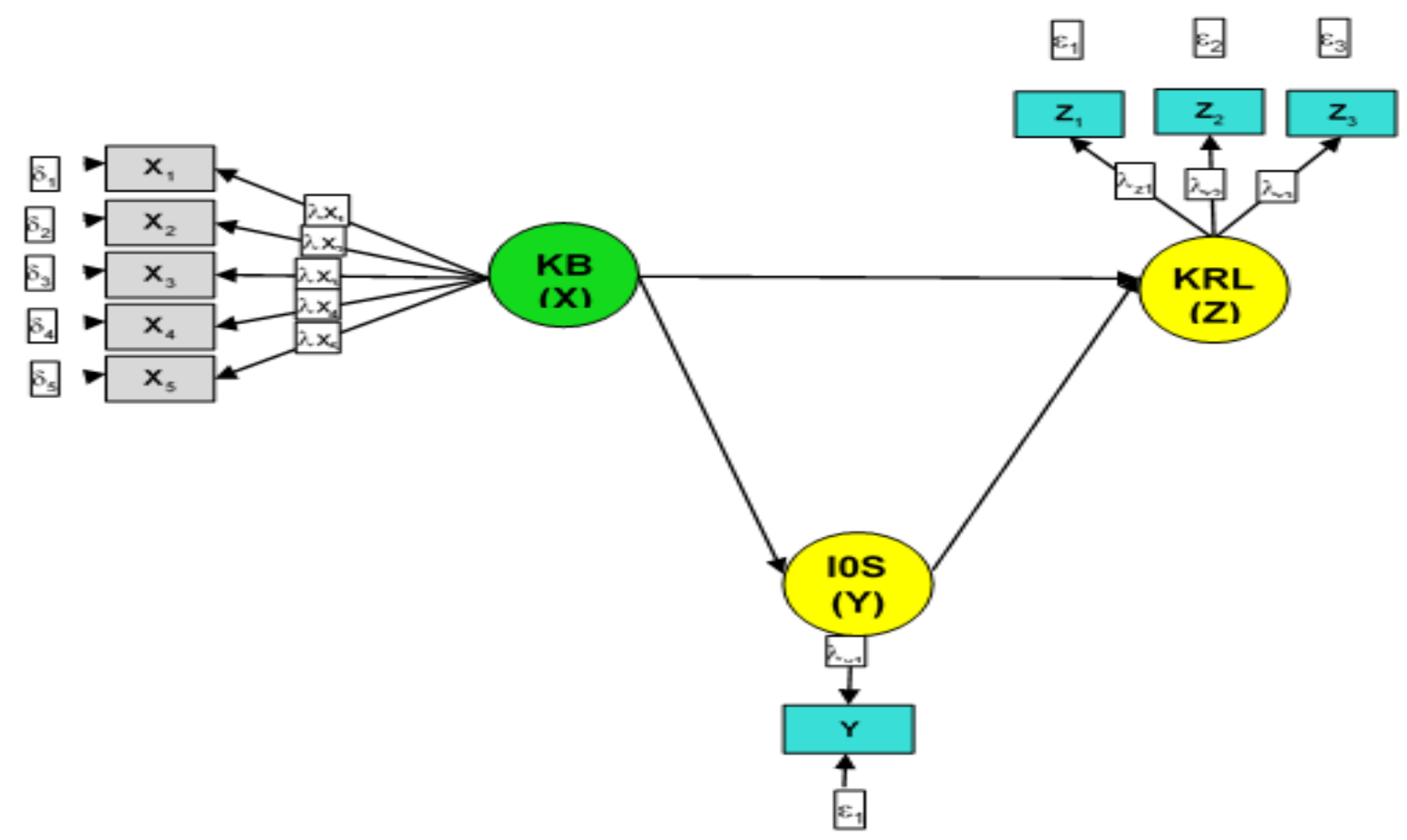

Gambar 3

Model standardized (PLS Algorithm)

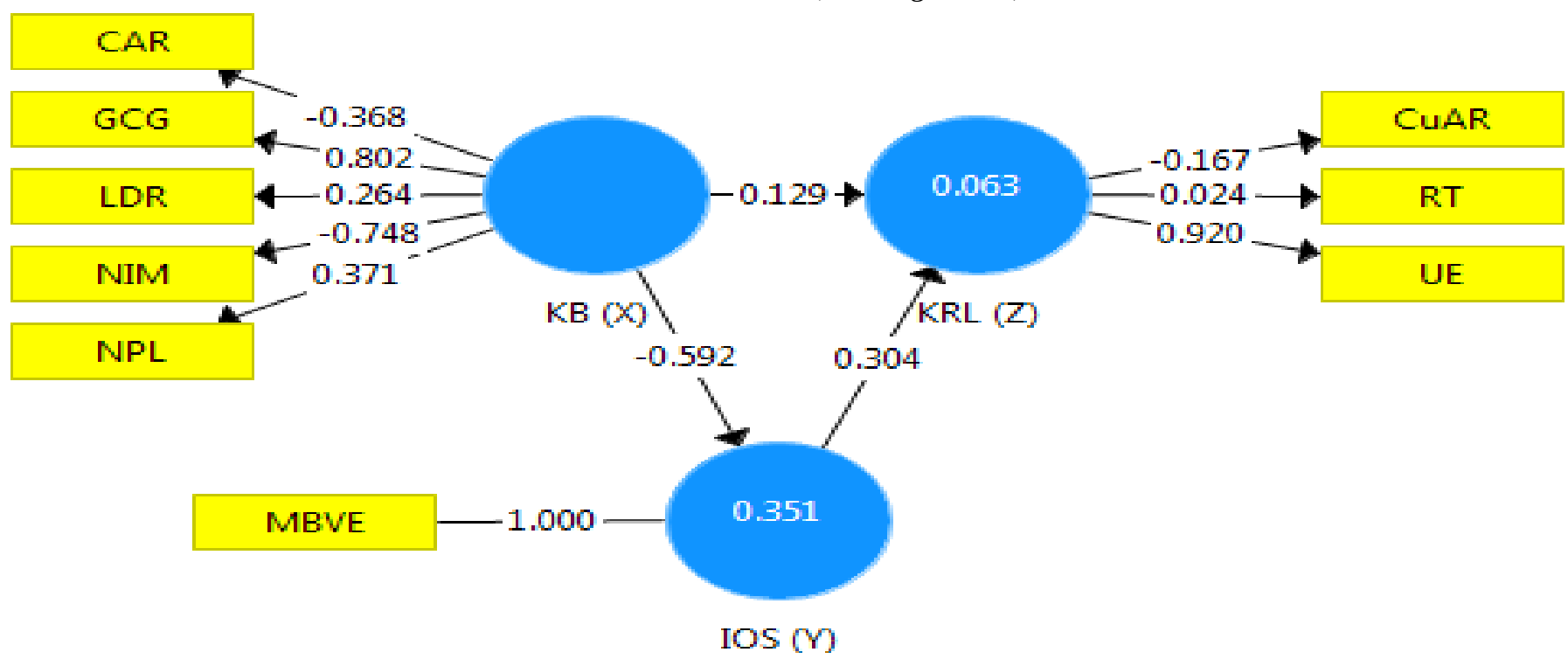

Hasil run smart PLS pertama untuk melihat hasil yang sesui dengan teori. Gambar dibawah adalah hasil run smartPLS Algoritma setelah nilai yang tidak sesuai dengan teori harus dihilangkan atau di hapus.

Gambar 4

Model Pengukuran Hasil Run SmartPLS Algorithm 


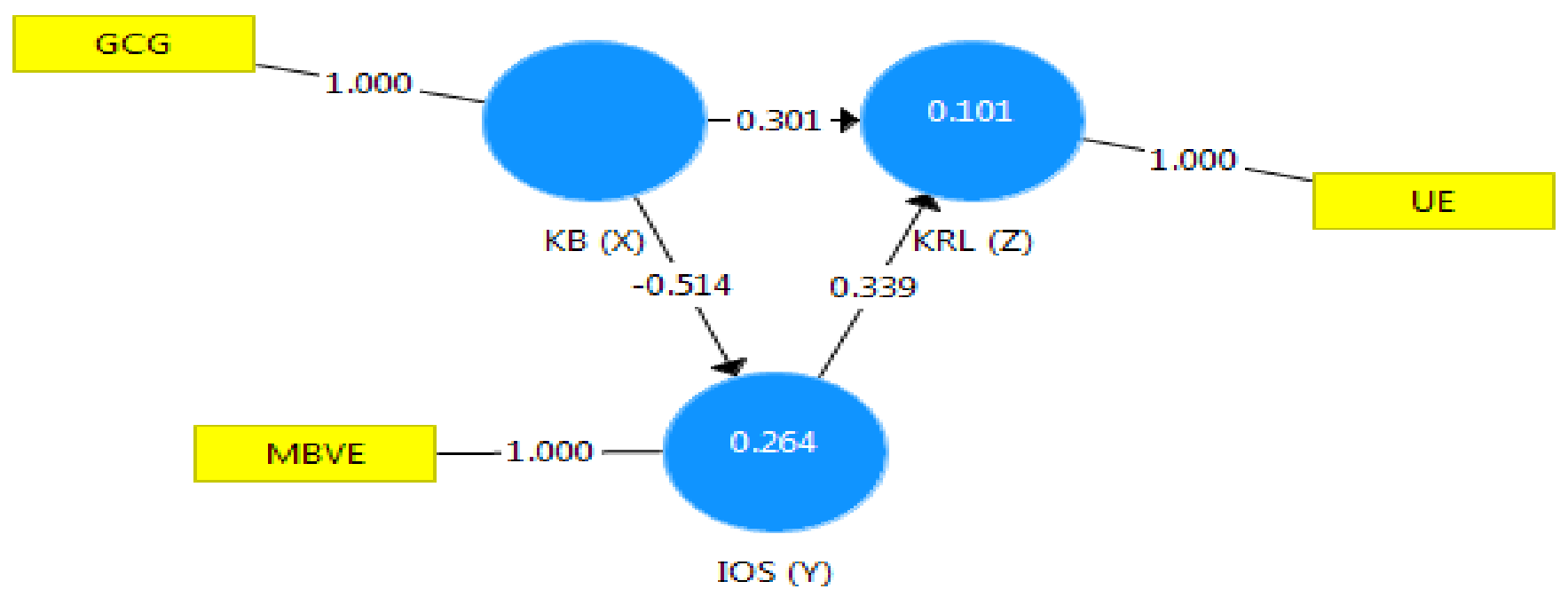

\section{Model Pengukuran Hasil Run SmartPLS Algorithm}

Gambar 5

Model $t$-Values (Bootsrapping)

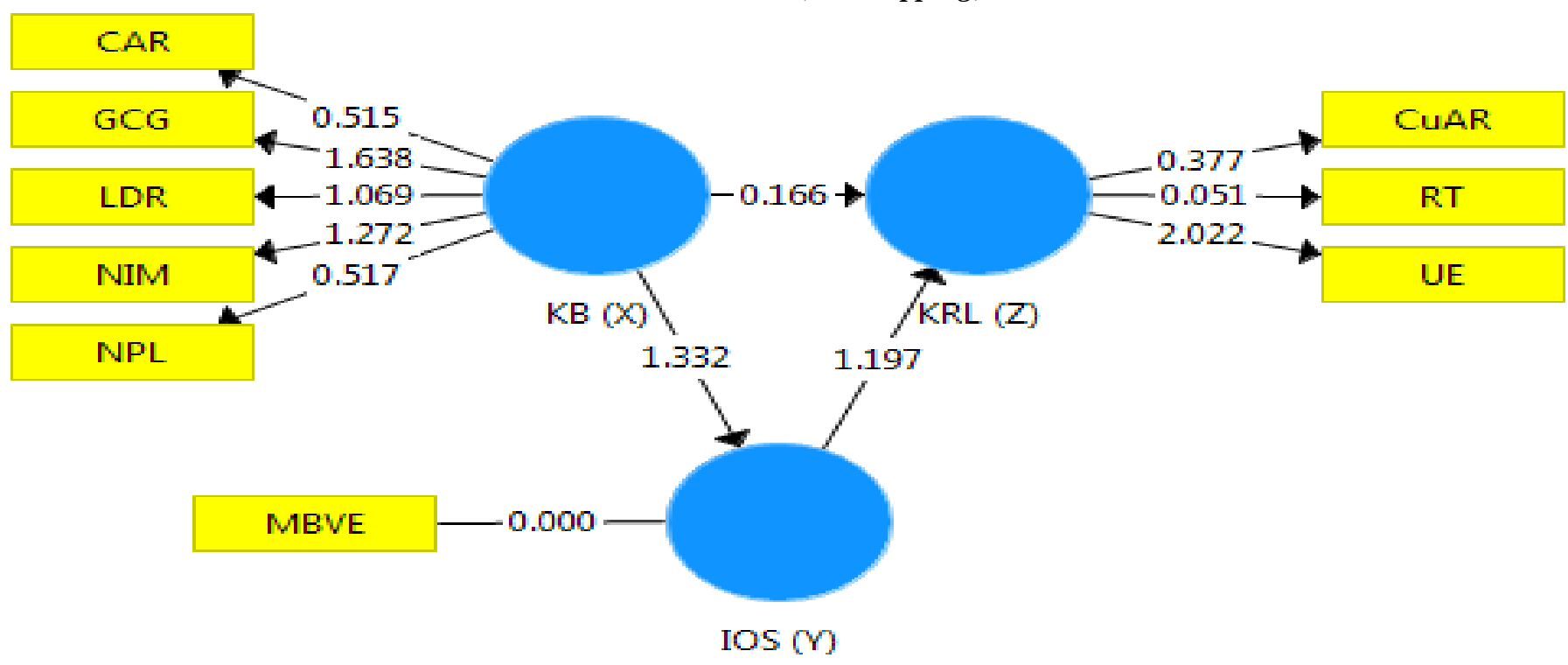

Hasil run smartPLS Bootsrapping pertama untuk melihat hasil yang sesui dengan teori. Gambar dibawah adalah hasil run smartPLS Bootstrapping setelah nilai yang tidak sesuai dengan teori harus dihilangkan atau di hapus.

\section{Gambar 6}




\section{Model Pengukuran Hasil Run smartPLS Bootstrapping}

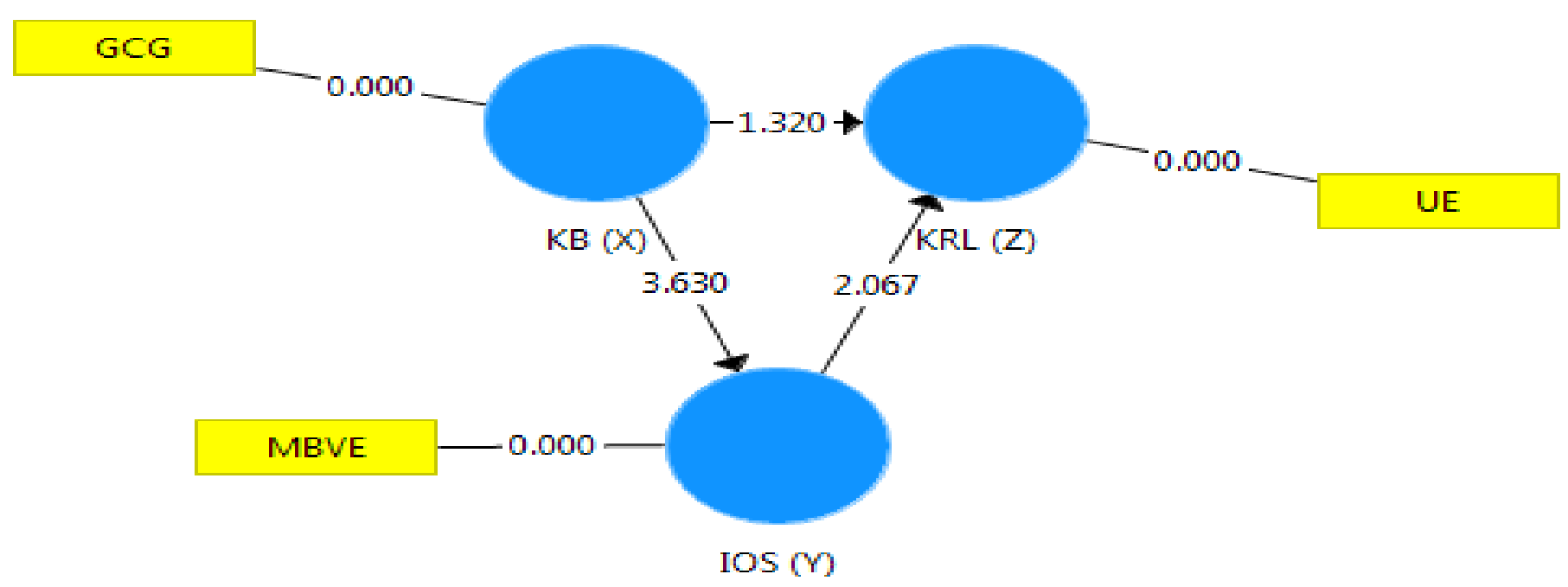

\section{Pengaruh Kinerja Keuangan Bank Terhadap Koefisien Respon Laba}

kinerja keuangan bank dan koefisien respon laba perusahaan perbankan dianalisis dengan melihat convergent validity masing-masing indikator. Hasil output menunjukan bahwa loading factor untuk konstrak kinerja keuangan bank cukup tinggi dengan yang dipersyaratkan minimum 0,6. Reliabilitas konstrak kinerja keuangan bank juga cukup tinggi yang ditunjukan oleh nilai reliabiliti komposit 1,000, nilai cronbach's alpha tinggi 1,000 yang keduanya diatas yang dipersyaratkan minimum 0,70 serta nilai average extract varians (AVE) 1,000 diatas yang dipersyaratkan yaitu 0,5. Hasil output loading factor untuk konstrak koefisien respon laba cukup tinggi dibawah yang dipersyaratkan yaitu 0,6. Reliabilitas konstrak koefisien respon laba ditunjukan oleh nilai composite reliability 1,000 dan nilai cronbach alpha 1,000 dipersyaratkan minimum 0,70, serta nilai average extract variance (AVE) 1,000 diatas yang dipersyaratkan lebih besar dari 0,5 .

Hasil output bootstrapping memberikan nilai signifikansi dari masing-masing indikator terhadap konstrak kinerja keuangan maupun koefisien respon laba dan investment opportunity set perusahaan perbankan. loading factor untuk indikator kinerja keuangan bank yaitu GCG yaitu sebesar 1,000 indikator koefisien respon laba yaitu UE sebesar 1,000 dan indikator investment opportunity set yaitu MBVE sebesar 1,000 semuanya signifikan dengan nilai nilai $t$ statistic diatas 2 (untuk tingkat signifikansi 0,05). Demikian juga dengan convergen validity dan discriminant validity tidak semua indikator kinerja keuangan bank dan koefisien respon laba memiliki convergen validity dan discriminant validity yang cukup tinggi.

Tabel 2

Path Coefisien Konstrak Kinerja Keuangan Bank dengan Koefisien Respon Laba

\begin{tabular}{|c|c|c|c|c|c|}
\hline & Sampel Asli (O) & Sample Mean (M) & Standar Deviasi (STDEV) & T Statistik (| O/STDEV |) & P Values \\
\hline KB (X) -> KRL (Z) & 0,301 & 0,268 & 0,228 & 1,320 & 0,197 \\
\hline Kinerja bank $->$ Koefisien respon laba & $\begin{array}{l}\text { R Square } \\
0,000\end{array}$ & & & & \\
\hline
\end{tabular}

Sumber : data olahan

Hubungan kinerja keuangan bank dengan koefisien respon laba memiliki koefisien parameter sebesar 0,301 dan nilai $t$ statistik 1,320 karena nilai $t$ statistik $(1,320)<2$ (untuk tingkat signifikansi 0,05 ) maka dapat disimpulkan bahwa kinerja keuangan bank berpengaruh dan tidak signifikan terhadap koefisien respon laba atau Ho diterima.

\section{Pengaruh Kinerja Keuangan Bank Terhadap Investment Opportunity Set}

konstrak kinerja keuangan dan investment opportunity set perusahaan perbankan dianalisis dengan melihat convergen validity masing-masing indikator. Hasil output menunjukan bahwa loading faktor untuk konstrak kinerja keuangan cukup tinggi diatas yang dipersyaratkan 0,6. Reliabitas konstrak kinerja keuangan bank juga cukup tinggi yang ditunjukan oleh nilai composite reliability yaitu 1,000 serta nilai cronbach alpha 1,000 serta nilai AVE sebesar 1,000 diatas yang dipersyaratkan yaitu 0,5 . Hasil output menunjukan bahwa loading factor untuk konstrak investment opportunity set perusahaan perbankan cukup tinggi diatas yang dipersyaratkan minimum 0,6 sedangkan reliabilitas konstruk investment opportunity set perusahaan perbankan juga cukup tinggi yang ditunjukan oleh nilai composite 
reliability 1,000 nilai cronbach alpha sebesar 1,000 yang keduanya dipersyaratkan minimum 0,7 serta nilai average extract variance (AVE) 1,000 diatas yang dipersyaratkan lebih besar dari 0,8. Hasil output bootstrapping memberikan nilai signifikansi dari masing-masing indikator terhadap konstrak kinerja keuangan bank maupun konstrak investment opportunity set perusahaan perbankan. Besar loading faktor untuk indikator kinerja keuangan bank yaitu GCG dengan nilai 1,000. Sementara besar loading faktor untuk indikator investment opportunity set adalah MBVE sebesar 1,000 signifikan dengan nilai $\mathrm{t}$ statistic diatas 2 (untuk tingkat signifikansi 0,05 ) demikian juga dengan convergent validity indikator kinerja keuangan memiliki discriminant validity yang cukup tinggi dan indikator investment opportunity set memiliki convergent validity dan discriminant validity yang cukup tinggi.

Tabel 3

Path Coefisients Konstruk Kinerja Keuangan dan Investment Opportunity Set

\begin{tabular}{|c|c|c|c|c|c|}
\hline & Original sampel (0) & Sampel mean (M) & Standar deviasi (ST DEV) & T Statistik ( O/STDEV D) & P Vahes \\
\hline KB $(X)->\operatorname{IOS}(Y)$ & $-0,514$ & $-0,525$ & 0,142 & 3,630 & 0,001 \\
\hline & R Square & & & & \\
\hline Kinerja bank->IOS & 0,101 & & & & \\
\hline
\end{tabular}

Sumber : olahan data

Berdasarkan tabel diatas dapat dijelaskan hubungan kinerja keuangan dengan investment opportunity set memiliki koefisien parameter sebesar -0,514 dan nilai t statistic sebesar 3,630 karena nilai t statistic 3,630 > 2 (tingkat signifikansi 0,05) maka dapat disimpulkan bahwa kinerja keuangan bank berpengaruh signifikan terhadap investment opportunity set atau Ha Diterima.

\section{Pengaruh Investment Opportunity Set Terhadap Koefisien Respon Laba}

Konstrak investment opportunity set dan koefisien respon laba perusahaan perbankan dianalisis dengan melihat convergen validity masing-masing indikator. Hasil output menunjukan bahwa loading faktor untuk konstrak investment opportunity set cukup tinggi diatas yang dipersyaratkan 0,6 . Reliabitas konstrak investment opportunity set juga cukup tinggi yang ditunjukan oleh nilai composite reliability yaitu 1,000 serta nilai cronbach alpha 1,000 serta nilai AVE sebesar 1,000 diatas yang dipersyaratkan yaitu 0,5. Kemudian hasil output menunjukan bahwa loading factor untuk konstrak koefisisen respon laba perusahaan perbankan cukup rendah dibawah yang dipersyaratkan minimum 0,6 sedangkan reliabilitas konstruk koefisisen respon laba perusahaan perbankan juga cukup tinggi yang ditunjukan oleh nilai composite reliability 1,000 nilai cronbach alpha sebesar 1,000 yang keduanya dipersyaratkan minimum 0,7 serta nilai average extract variance (AVE) 1,000 dibawah yang dipersyaratkan yaitu dari 0,8. Hasil output bootstrapping memberikan nilai signifikansi dari masing-masing indikator terhadap konstrak investment opportunity set maupun konstrak koefisien respon laba perusahaan perbankan. output bootstapping besar loading faktor untuk indikator investment opportunity set MBVE sebesar 1,000. Sementara besar loading faktor untuk indikator koefisien respon laba adalah UE sebesar 1,000 signifikan dengan nilai t statistic diatas 2 (untuk tingkat signifikansi 0,05) demikian juga dengan convergent validity indikator investment opportunity set memiliki convergent validity dan discriminant validity yang cukup tinggi. Sedangkan koefisien respon laba tidak semua memiliki convergen validity dan discriminant validity yang cukup tinggi.

Tabel 4

Path Coefisients Konstruk Investment Opportunity Set dan Koefisien Respon Laba

\begin{tabular}{|c|c|c|c|c|c|}
\hline & Original sampel (0) & Sampel mean (M) & Standar deviasi (STDEV) & T Statistik (| O/STDEV |) & P Values \\
\hline IOS->KRL & 0,339 & 0,285 & 0,164 & 2,067 & 0,047 \\
\hline & R Square & & & & \\
\hline IOS->KRL & 0,264 & & & & \\
\hline
\end{tabular}

Sumber : olahan data

Berdasarkan tabel diatas dapat dijelaskan hubungan investment opportunity set denga koefisien respon laba memiliki koefisien parameter sebesar 0,339 dan nilai t statistic sebesar 2,067 karena nilai t statistic 2,067 > 2 maka dapat disimpulkan bahwa investment opportunity set berpengaruh signifikan terhadap koefisien respon laba atau Ha diterima.

\section{Simpulan}

Berdasarkan hasil penelitian dapat ditarik kesimpulan sebagai berikut: kinerja keuangan bank berpengaruh tidak signifikan terhadap koefisien respon laba atau Ho diterima. Kinerja keuangan bank berpengaruh negatif dan signifikan terhadap investment opportunity set atau Ha diterima. investment opportunity set berpengaruh signifikan terhadap koefisien respon laba atau Ha diterima. 
Atti Rasnawati, Pengaruh Kinerja Keuangan Bank Terhadap Koefisien Respon Laba Melalui Investment Opportunity Set (Studi Kasus pada Bank Umum yang Terdaftar di Bursa Efek Indonesia Periode Tahun 2011-2016)

\section{Daftar Pustaka}

Arta, I.K. W.P dan L.K. Sudjarni. 2014. Pengaruh Kinerja Keuangan terhadap Return Saham Perusahaan Sektor Food and Baverage di BEI. Jurnal Manajemen Universitas Udayana 3: (3).

Brigham, E.F dan J.F. Houston. 2006. Dasar-Dasar Manajemen Keuangan. Edisi Sepuluh. Salemba Empat. Jakarta.

Fahmi, Irham. 2011. Analisa Laporan Keuangan. Alfabeta. Bandung. Jurnal Ilmu dan Riset Manajemen Volume 6, Nomor 2, Februari 2017 ISSN : 2461-0593. 2012. Analisis Laporan Keuangan. Cetakan Ke-2. Alfabeta. Bandung.. 2014. Analisis Laporan Keuangan. Alfabeta. Bandung.

Fatmawati. 2013. Analisis Pengaruh Rasio Aktivitas, Rasio Profitabilitas, Dan Rasio Pasar Terhadap Return Saham Perusahaan Grosir Dan Ritel Yang Terdaftar Dalam Efek Syariah. Universitas Islam Negeri Sunan Kalijaga. Yogyakarta.

Gaver, J.J. dan K.M Gaver. 1993. Additional Evidence on the Association between the Investment Opportunity Set and Corporate Financing, Dividend, and Compensation Policies. Journal of Accounting and Economics 16:125160

Ghozali, I. 2013. Aplikasi Analisis Multivariate dengan Program SPSS. Edisi Ketujuh. Badan Penerbit Universitas Diponegoro. Semarang.

Hanafi. 2004. Manajemen Keuangan. BPFE-UGM. Yogyakarta.

Harahap, S.S. 2009. Teori Kritis Laporan Keuangan. Bumi Aksara. Jakarta.

Husnan, S. 2009. Dasar-Dasar Teori Portofolio dan Analisis Sekuritas. Edisi Keempat. UPP STIM YKPN. Yogyakarta. Ismayanti, D dan W.M.Yusniar. 2014. Pengaruh Faktor Fundamental dan Resiko (Beta) terhadap Return Saham pada Perusahaan yang termasuk dalam Indeks LQ 45. Jurnal Wawasan Manajemen 32: (1).

James, C.V.H. dan J. M. Wachowicz. 2005. Prinsip-Prinsip Manajemen Keuangan. Edisi Kedua Belas. Salemba Empat. Jakarta.

Jogiyanto, H.2005.Analisis dan Desain Sistem Informasi Pendekatan Terstruktur Teori dan Praktek Aplikasi Bisnis. Andi Offset. Yogyakarta 2010.Teori Portofolio dan Analisis Investasi. Edisi Ketujuh. BPFE-UGM.Yogyakarta.

Kasmir. 2012. Analisis Laporan Keuangan. Cetakan Kelima. PT. Raja Grafindo Persada. Jakarta. 2013. Analisis Laporan Keuangan. Edisi Satu. Cetakan Keenam. Rajawali Pers. Jakarta.

Lukman, Dendawijaya. 2009. Manajemen Perbankan. Ghalia Indonesia. Jakarta.

Munawir, S. 2007. Analisis Laporan Keuangan. Liberty. Yogyakarta.

Murhadi, W.R. 2013. Analisis Laporan Keuangan, Proyeksi dan Valuasi Saham. Salemba Empat. Jakarta.

Nudiana, R. 2013. Pengaruh Rasio Likuiditas, Leverage, Aktivitas, Profitabilitas Terhadap Return Saham pada Perusahaan Food and Baverage yang Terdaftar di BEI. Jurnal Ilmu dan Riset Manajemen $2: 4$.

Norpratiwi, M.V.A. 2004. Analisis korelasi investment opportunity set terhadap Return Saham. Tesis. Program Pasca Sarjana Universitas Gajah Mada. Yogyakarta

Pagalung, G. 2003. Pengaruh Kombinasi keunggulan dan keterbatasan Perusahaan terhadap Set Kesempatan Investasi (IOS). Jurnal Riset Akutansi Indonesia 6(3): 249-264.

Riyanto, B. 2001. Dasar-Dasar Pembelanjaan Perusahaan. Edisi Keempat. BPFE. Yogyakarta.

Rusdin. 2008. Pasar Modal : Teori, Masalah, dan Kebijakan dalam Praktik. ALFABETA. Bandung.

Shintawati, V.R. 2011. Pengaruh board Diversity, Investment Opportunity Set (IOS), dan Kinerja Keuangan terhadap Nilai Perusahaan yang Terdaftar di Bursa Efek Indonesia Tahun 2008. Fakultas Ekonomi Universitas Sebelas Maret. Yogyakarta.

Parameswari, Silvia Y. Simatupang, M. 2010. Pengaruh Kinerja Keuangan... Pengetahuan Praktis Investasi Saham dan Dana Reksa. Mitra Wacana Media. Jakarta.

Singarimbun, M. 1985. Metode Penelitian Survey. PT. Pustaka LP3ES Indonesia. Jakarta.

Smith, C.W. dan R.L.Watts. 1992. The Invesment Opportunity Set and Corporate Financing, Devidend, and Compensation Policies. Journal of Financial Economics 32: (263 -292).

Sugiyono.2008. Metode Penelitian Pendekatan Kuantitatif, Kualitatif, dan R dan D.Alfabeta. Bandung.

-----2009. Statistika Untuk Penelitian. Cetakan Enam Belas. Alfabeta. Bandung.

Sukirman, Sugiarto dan Kartika. 2011. Pengaruh Kinerja Keuangan dan Kinerja Manajerial terhadap Return Saham (Studi Pada Perusahaan Manufaktur yang Terdaftar di BEI). Jurnal Aplikasi Manajemen 4.

Suryani, Arna. 2017. Koefisien Respon laba dan Manajemen laba(studi konservatism). Tangga Ilmu. Yogyakarta.

Tandelilin, E. 2001. Analisa Investasi dan Manajemen Portofolio. BPFE. Yogyakarta. 2010. Portofolio dan Investasi Teori. Edisi Pertama. KANISIUS. Yogyakarta.

Terestiani, D.P. 2011. Pengaruh Investment Opportunity Set dan Struktur Modal Terhadap Return Saham pada Perusahaan Farmasi di Bursa Efek Indonesia. Tesis. Program Pasca Sarjana Universitas Udayana. Denpasar. 
Atti Rasnawati, Pengaruh Kinerja Keuangan Bank Terhadap Koefisien Respon Laba Melalui Investment Opportunity Set (Studi Kasus pada Bank Umum yang Terdaftar di Bursa Efek Indonesia Periode Tahun 2011-2016)

Utami Sih Widhi, 2007. Asosiasi antar investment. Fatimah jinnah women university, rawalpindi, BUSINES AD > BUSINES AD $28>$ JAK2012.

Indonesia stock exchange 2016. IDX Quartely statistic. Quarter 2016. Melalui http : // www. Idx.co.id

Kapitalisasi pasar, saham Ok. 2010-2016. Melalui http : // www.saham Ok. com //emiten / kapitalisasi pasar/ 20102016.

Historical price - yahoo finance tahun 2010-2017 melalui http:// Finance yahoo.com/ 2010-2017.

Laporan tahunan sektor keuangan sub sektor bank tahun 2010-2016. 